\title{
The Crisis of German Social Democracy Revisited
}

\author{
JÖRG MICHAEL DOSTAL
}

\begin{abstract}
This article analyses the dramatic electoral decline of German social democracy since 2003. It argues that the SPD's decision, under the leadership of former Chancellor Gerhard Schröder, to engage in welfare state retrenchment and labour market deregulation during the 'Hartz reforms' (2003-05) demoralised the SPD electorate. The SPD subsequently lost half of its former electoral coalition, namely blue-collar voters and socially disadvantaged groups, while efforts to gain access to centrist and middle-class voters have failed to produce any compensating gains. While the SPD's decline from a large to a mid-sized party is part of a larger transformation of the German party system, no political recovery is possible for social democracy without a fundamental change of strategy, namely efforts to regain former voters by offering credible social welfare and redistributive policies. The SPD will not be able to delegate such policies in a 'convoy model' to other parties, such as the Left Party; nor will a modest 'correction' of the earlier course, such as has been attempted since 2009 under the leadership of current party chairman Sigmar Gabriel, be sufficient to recover lost electoral ground.
\end{abstract}

Keywords: German party system, German politics, Hartz reforms, Left Party, SPD

\section{Introduction}

Continental European social democracy has not fared well in the twenty-first century. Wherever social democratic parties used to be significant actors in national party systems, they have either nearly disappearedsuch as in Greece - or have faced dramatic electoral decline. In the past fifteen years, this has particularly been the case for social democrats in Germany (SPD), France (PS) and Spain (PSOE), to name only the major west European cases. In each of those three cases-and similar developments apply in smaller continental European countries, such as Austria (SPÖ) - the electoral decline had a clear starting point, namely the explicit endorsement of neoliberal supply-side reform by social democratic party leaders.

The first mover in this respect was German Chancellor Gerhard Schröder's supplyside reforms of the German labour market, which began in 2003. These are known as the 'Hartz reforms', named after a then human resources manager at Volkswagen who acted as Schröder's assistant in setting the agenda, although the SPD soon renamed the programme 'Agenda 2010'. The Hartz and Agenda reforms turned out to amount to a general remodelling of German capitalism post-unification. These reforms symbolised the transition from an earlier neo-corporatist to a new supply-sideoriented form of labour market governance in Germany. ${ }^{1}$ Even more importantly, they stood for a philosophical and normative shift in the attitudes of leading social democratic policy-makers, away from a welfare state based on collective risk sharing of wage earners in the social insurance system toward a new ethic based on burden-shifting from welfare-state institutions to individual employees and private households. ${ }^{2}$

In particular, the Hartz and Agenda policies expanded non-regular forms of employment, such as fixed-term and agency employment with lower standards of social protection, and introduced large-scale cuts in welfare and social insurance entitlements. Around the time of the Hartz reforms, there 
were also cuts in pension levels in the public pension system in favour of newly established individual private insurance on a voluntary basis (the so-called 'Riester-Rente'). All these reforms amounted to the most dramatic retrenchment of employment standards and social policies in the history of the Federal Republic. A newly introduced welfare benefit of last resort-the so-called 'Hartz 4' system, designed to exclude the long-term unemployed and other disadvantaged groups from the scope of social insurance-became a notorious symbol of the new order. The new policy triggered the largest ever street protest movement in the history of the unified Germany when millions of people participated over the course of months, and in some cases years, in street rallies against the Hartz reforms.

The outcome of this extra-parliamentary mobilisation (the so-called 'anti-Hartz movement') might be summarised as follows: (1) the alliance between the SPD and the trade unions broke down and the latter mobilised, for the first time in their history, on a broad scale against SPD policies; (2) the Hartz reforms produced a split inside the SPD, and a leftist faction resigned from the party to join forces with the predominantly East German Party of Democratic Socialism to form the Left Party, which subsequently became an established fixture in the German party system; (3) the SPD suffered the largest electoral decline in the party's history.

In brief, the 2003-05 policies of the Schröder SPD attacked their own electorate, especially working-class constituencies in declining economic sectors and socially disadvantaged groups. They broke the social contract to defend high standards of employment rights and welfare entitlements for core workers that had underpinned the longstanding alliance between the SPD and the trade unions and had largely become the norm in West Germany since the 1960s. While various disadvantaged groups and the less established sectors of the working class had never been fully represented by the SPD -a party traditionally dominated by skilled workers, the Facharbeiter, and later, since the 1970s, by civil servants and sections of the new middle class - they had nevertheless usually joined forces with the skilled sectors of the labour movement at the ballot box by voting SPD, since voting for the conservative parties did not normally provide a promising alternative.

For the SPD, the political cost of the Hartz and Agenda policies has been very high: the party has lost around half of the electoral support it was previously able to claim. The electoral downturn began between 2003 and 2005 when the reforms were announced and implemented, and continued in the federal elections of 2009 and 2013. The electoral decline has not reversed since then, and the SPD is no longer able to compete with the centre-right Christian Democrats (the CDU/ CSU) on an equal basis. ${ }^{3}$ In post-Hartz German politics, the SPD has lost its earlier status of Volkspartei, the German term to indicate a catch-all and potential majority party representing a large segment of the electorate. Instead, in many areas the SPD now holds the status of a mid-sized or even small party, such as in the regions (Länder) of Baden-Württemberg, Thüringen and Sachsen, where the most recent electoral results, between 2014 and 2016, gave it only between 12.4 and 12.7 per cent of the vote. In these three Länder the SPD finished only as the third or fourth largest party, in an increasingly diverse party system in which it is frequently overtaken by the Left Party, the Greens and the right-wing Alternative for Germany (AfD), as well as the Christian Democrats.

This article sets out to explain the electoral decline of the SPD since 2003. First, the political background of the Hartz reforms and the SPD's leadership role in this context is briefly outlined. Then, three major issues will be covered: (1) people and ideas; (2) policies and institutions; and (3) the future role of the SPD in the changing German party system.

\section{Germany: from neo-corporatism to the Hartz reforms}

Before the Hartz reforms, the German model of capitalism (the Modell Deutschland) was largely based on neo-corporatist structures. Labour and social policy-making was farmed out from the political system in the narrow sense to social partners, namely employer associations and trade unions. In addition, there existed a dense network of civil society 
associations, churches, welfare-providing associations and other long-standing interest groups. These institutions, some with roots in the traditional workers' movement and others in Christian social teaching, provided a training ground for the personnel of Germany's main political parties.

The governance of the system was based on tripartite-style coordination, i.e. joint governance by state officials, employer representatives and unions that extended to various institutions such as unemployment insurance, vocational training systems and labour market governance. As for Parliament, the Labour and Social Affairs Committee and the party specialists associating there were socialised to accept this system as the natural way of doing business.

Following German unification, there were efforts to extend the West German neo-corporatist system to the East. However, the necessary institutional preconditions were absent and social upheaval in East Germany, combined with extremely high unemployment levels, meant that the system of the west was transferred in name only. In the mid-1990s, it became clear that the East German labour market would largely remain outside the scope of employer associations and unions, since deindustrialisation produced a fragmented employment system without large employers or a strong union presence.

Furthermore, since the German social insurance system is largely financed by levies on employers and employees, the drop in revenue due to high unemployment postunification led many German economists to argue that these levies (Lohnnebenkosten) were too high, thereby undermining German competitiveness and employment levels. The existing system of labour market governance rather than the economic shock of unification was blamed for the crisis. Paradoxically, it was only after the 1998 change in government from the centre-right (CDU/CSU and liberals) to the centre-left (SPD and Greens) that policy-making started to shift in line with the prescriptions of neoliberal economists.

The change in government in 1998 and the narrow re-election of the SPD and Green government in 2002 took place in the context of generational change in all political parties. The 'welfare state generation' of CDU/CSU and SPD politicians that had dominated the system since the 1970s, and that had deep roots in welfare-state associations, unions and the public sector, retired from politics. The new generation of politicians, in both the CDU/CSU and the SPD, had by contrast advanced either along the path of party-political careers or had general professional backgrounds rather than an interest in social policy. ${ }^{4}$

In the SPD, the power struggle between Gerhard Schröder as Chancellor and Oskar Lafontaine as SPD chairman and, briefly, economics minister (between 1998 and 1999) resulted in the latter's resignation from office. This signalled the defeat of the leftists in the SPD and opened the gates for a new group of SPD politicians directly connected with Schröder to enter influential positions in party and government. These newcomers were no longer connected with traditional labour and social policy interests, and their career advancement depended solely on serving the party leadership.

\section{The SPD in transition: 1998 and 2002}

In SPD circles, debate about supply-side reform in the labour market was largely avoided between 1998 and 2002. The only high-profile attempt to raise 'ideological' issues - the so-called 'Schröder-Blair paper' of June 1999, jointly written by Bodo Hombach, then head of Schröder's chancellery, and Peter Mandelson, at that point a backbench MP but still close to the Blair leadership_called for a 'supply-side oriented agenda', 'flexible goods, capital and labour markets' and 'necessary cuts in public spending'. The paper triggered a brief but angry reaction within the SPD and the possibility of further discussion was quickly dropped. Until the 2002 federal election, Schröder and the SPD appeared to be unified in efforts to keep labour-market issues off the agenda in order to fight elections against an increasingly neoliberal CDU/CSU opposition, which demanded large-scale retrenchment of welfare-state institutions.

Shortly before the 2002 federal elections, Chancellor Schröder outsourced further reform debate to the Hartz Commission (on 
labour market reform) and, shortly after the election, to the Rürup Commission (on pension reform). Both commissions were ad hoc bodies without any clear status and were appointed at the Chancellor's pleasure. The commissions were dominated by representatives of private corporations and served the purpose of setting policy agendas that could be pushed through the federal parliament and the second chamber of the regions (Bundesrat) without further debate. However, the CDU/CSU held the majority in the second chamber, a potential veto point in Germany's multilevel governance. Thus, the reform agenda required the opposition's support, which was forthcoming in due course and helped Schröder to present his policies as a foregone conclusion to his own party.

Following the 2002 federal elections that were narrowly won by the SPD and Greens, Schröder announced the Hartz reforms for implementation on a 'take-it-or-leave-it' basis in a speech to the federal parliament on 14 March 2003. He demanded that his party follow his course and was supported in this imposition by a small group of assistants that became known as the SPD's 'Agenda wing'. This dramatic shift toward supplyside policies clearly shocked the SPD's rankand-file and amounted to 'policy-seeking' at the expense of 'vote-seeking'. Following Schröder's announcements in Parliament, the SPD suffered dramatic electoral declines in every subsequent election and at each level of the German federal system. In parallel, SPD membership figures dropped and the leftist SPD wing resigned to join forces with the PDS to form the new Left Party. After the SPD's dramatic electoral defeat in its former stronghold of North-Rhine Westphalia in 2005, Schröder decided to seek a new mandate for his policies. He called for early federal elections and lost narrowly to Angela Merkel's CDU, at which point he retired from politics.

From the point of view of the SPD, the main concern was that the party received the lion's share of the electoral punishment for the unpopular labour market deregulation and welfare retrenchment policies. The CDU/CSU fared comparatively better, since its electoral base was economically more secure and less dependent on welfare state policies. Some SPD politicians subsequently tried to blame the CDU/CSU for imposing more drastic cuts in social protection in the process of negotiating over Hartz and subsequent reform packages in the second chamber of parliament, but this strategy of blame-shifting failed to work: the German public held Chancellor Schröder, rather than the opposition leader Angela Merkel, politically responsible. The SPD suffered what could only be described as a breakdown of its electoral base, and the number of SPD voters declined from 20 million in 1998 to less than 10 million in 2009.

\section{People and ideas in the SPD}

At the level of party personnel, the SPD proved unable to react to negative electoral feedback about Agenda policies. One symbol of this was the party's failure to find new leaders with new ideas. Thus, when Schröder resigned from his position as SPD chairman in 2004 due to his unpopularity with the membership, the party elite followed his suggestion to appoint as his successor Franz Müntefering, a person who had served as Schröder's right-hand man and who symbolised the party's 'Agenda wing'. After losing the 2005 federal elections and joining the new Chancellor Angela Merkel in a grand coalition government as a junior partner, the SPD went through three other party chairmen in quick succession, briefly reappointing Müntefering between 2008 and 2009.

Only after the even more crushing federal election defeat of 2009 did the SPD appoint Sigmar Gabriel, one of the very few prominent SPD politicians who had kept some distance from the Agenda policies, as its new chairman. Yet this belated change of course occurred only when most of the representatives of the 'Agenda wing' in the SPD had in turn decided to resign from politics. Thus, the new SPD leadership, still in place today, reached their positions due to the exhaustion of the 'Agenda wing' rather than any open political challenge of the earlier course.

As for political ideas, one might stress that the SPD had faced, for the entire period between 1998 and 2009, a strategic dilemma. On the one hand, Germany had been increasingly influenced by neoliberal ideas since the 1990s and the SPD had already lost confidence in national neo-Keynesian policies 
before $1998 .{ }^{5}$ Yet this transition at the level of economic doctrine had never been made fully explicit and was not matched by changes in electoral strategy. In the past, the SPD had always claimed that the party would guarantee high levels of social protection to core workers as a reward for good performance in the workplace. Yet the 'Agenda wing' of the SPD no longer offered such assurances: under the Schröder and Müntefering leaderships, the party announced that retrenchment was the only way to restore German economic competitiveness and that workers were simply expected to pay the necessary price through cuts to their living standards, social security and future pensions.

Moreover, the retrenchment of welfare guarantees, especially the limitation of unemployment insurance payments to a single year, followed by the demand on the unemployed to use up their personal savings (and those of their partners) before qualifying for any further means-tested welfare payments, suggested an expansion of the zone of economic precariousness. Postreform, losing one's job once again became an existential challenge to one's social status: no matter how long and how much people had paid into the social insurance system, they no longer received reliable levels of protection. Thus, by devaluing the explicit and implicit promises of the German welfare state and by increasing pressure on the unemployed to accept any kind of employment regardless of pay and conditions, the new policies became a very strong device to restore 'discipline' in the labour market.

Yet by attacking its own core electoral support group, the SPD destroyed the basis of its past electoral success and created a general feeling of demoralisation among the rank-and-file. In 2009, former SPD voters left in virtually all directions, especially toward non-voting, the Left Party and the Greens (in that order). However, a sizable cohort also turned away from the centre-left electoral camp and moved to the right-initially to the $\mathrm{CDU} / \mathrm{CSU}$ and the Liberals, but more recently, since 2013, to the new AfD party. Thus, the conventional wisdom suggesting that elections are won in the centre proved to be true only as long as the leftist electorate and the traditional working-class groups - two different but significant components of the SPD's former electoral coalition -were not completely abandoned. This was patently not the case after 2003.

To be fair, the SPD made efforts to regain its former electorate after the poor results in the federal elections of 2009 and 2013. First, the party committed itself to a policy of 'corrections' of the earlier Hartz policies. In particular, the SPD agreed with an increasingly centrist CDU/CSU, which in turn had become less keen on neoliberalism due to the post-2008 crisis, to once again improve conditions in the unemployment insurance system for those who held long-term contribution records. In addition, the SPD put forward new welfare policies to make it easier for women to participate in full-time employment by improving state-supported childcare policies. More recently, and in reaction to the European Central Bank's low interest-rate policies that have triggered a rapid rise in asset prices in the German real estate sector and the stock market-a development that will not surprise an AngloAmerican readership - the SPD has also tried to reposition itself as the party defending the interests of people living in rented housing.

In addition, the party tried to gain a de facto feminist profile, although such efforts often triggered new misunderstandings. For example, the current SPD justice minister Heiko Maas suggested that divorced fathers who failed to pay child maintenance to their former partners should have their driving licences revoked. To many observers, such policies appeared as authoritarian and as a sure way to make divorced men become unemployable, meaning the punishment would make them even less likely to be able to pay child maintenance. ${ }^{6}$

More recently, the SPD chairman and current German Vice Chancellor Gabriel reacted to the refugee crisis and the increased number of migrants entering Germany in 2015 with demands to expand welfare policies for the native population in order to increase the public's willingness to pay for the social integration of newcomers. ' While correctly pointing out that Chancellor Angela Merkel's optimistic statement of 31 August 2015 that 'We can manage' with regard to the refugee crisis has largely not been borne out by reality on the ground, he failed to clarify how 
the SPD's own earlier welfare retrenchment could be reconciled with his new demands.

To be sure, the SPD leadership has merely been trying to appeal to different wings of the party's remaining electorate, including those sections that are critical of the high numbers of admitted refugees. Yet the idea that the situation demanded additional welfare rights for Germans was clearly something that the SPD had not been advocating before the 2015 refugee crisis, and the electorate could not help but notice. Thus, the move appeared opportunistic, at a moment in which the rightist AfD was quickly expanding its electoral appeal based on an anti-immigration platform.

Looking at the larger picture, the main problem of the SPD's new 'generosity' with regard to welfare policies - albeit with an authoritarian bent and closely related to the project of making full-time employment the only socially acceptable way of life-is that they lack credibility with voters and fail to address underlying structural problems. For example, promises to limit rent increases at a time when rent levels have been growing far above the official rate of inflation for a number of years ring empty. What all of the new employment-oriented welfare policies fail to address is the increased feeling of insecurity among the working public in general, which is directly due to the past policies of the SPD.

In conclusion, the SPD policies during the Hartz years from 2003 to 2005, the transition period away from these policies up to 2009 and the efforts taken since then to partially correct the previous course all failed in terms of delivering electoral support for the party. On the one hand, the traditional employee groups in declining economic sectors, historically associated with the SPD and the unions, turned away from the SPD toward non-voting, or switched to the Left Party. What remained of the SPD's support came to be concentrated among white-collar employees, civil servants and pensioners. On the other hand, those who won as a result of the structural economic changes did not support the SPD either. Instead, they voted for the centre-right parties setting out low tax policies, or supported the Greens as the party catering for an ecologically conscious and self-reflexive new bourgeois milieu that exists mostly at a safe distance from large private sector employers and unions. The SPD's change of course was not appreciated by the electorate.

\section{Policies and institutions: the new role of the SPD}

It is rather tempting to search for some larger meaning in the SPD's general failure to successfully contest elections over the past fifteen years or so. Could it be that there is some larger structural change at work that explains the party's behaviour, at least to some extent? Undeniably, one major possibility is structural change in the German employment regime. Such change might have motivated the SPD leaders to make an effort to appeal to upwardly mobile social groups (the 'winners') at the expense of delinking from declining sectors (the 'losers').

In this context, one significant shift in the German labour market is seen in the tendency for younger employees to hold higher educational qualifications compared to the older generation. Optimistic observers of this development suggest a 'competency revolution' - increased autonomy and control in the workplace-while pessimists highlight that increased educational credentials do not necessarily mean better job prospects or improved social positions, but could also point to the emergence of a 'colourful service proletariat $^{\prime} .8$

Back in 1991, a large percentage of employees in Germany held vocational training credentials (46 per cent), but by 2013 this figure stood at 29 per cent. In parallel, the share of employees with academic and semiacademic credentials grew from 32 per cent (1991) to 47 per cent (2013). The number of workers without formal qualifications or with limited 'on-the-job' training has remained largely stagnant, standing at 22 per cent in 1991 and 24 per cent in 2013. ${ }^{9}$ Thus, the centre ground of the German labour market is today defined by (semi-) professionals, while traditional groups of the working class have become to some extent marginalised.

Yet such structural change does not remove social insecurity: the 'new' groups 
often fail to earn more than their parents. Real wages in Germany fell or stagnated from the mid-1990s until very recently, while they grew in most other EU countries up to the 2008 crisis. Many of the newly created jobs are in deregulated sectors, based on fixed-term contracts and precarious social security. In particular, an increasing number of jobs are not covered by social insurance and are therefore considered 'non-standard' employment in the German context (the $M c J o b$ equivalent of Anglo-American capitalism). The share of standard employment declined from 79 per cent in 1991 to 68 per cent in 2014, while in 2014 the share of 'atypical employees' (i.e. those in fixed-term, agency or 'short hour' jobs) amounted to 21 per cent. Among the self-employed (11 per cent), more than half are solo-self-employed, meaning they are particularly exposed to changes in their individual circumstances. ${ }^{10}$

However one interprets such structural employment changes, it would be wrong to claim that employees have generally lost interest in collective risk-sharing and welfare state policies. Rather than pointing to increased 'self-responsibility' as a solution to new social risks, as did the Schröder SPD, the challenge is to reinvent social protection for a new generation. However, neither the SPD nor the other European social democratic parties have managed to develop such new policies. During the Schröder years up to 2005, and during the years of 'Agenda wing' dominance up to 2009, the SPD was at the forefront in pushing risk toward individual employees. ${ }^{11}$

This course never gained support among trade unions, with the exception of two individual trade union leaders representing the chemical and railway workers' unions, who were personally close to Schröder and subsequently received lucrative positions on company boards. This episode triggered much resentment among the rank-and-file and both union leaders subsequently left the scene in 2009. In general, unions have been united in demanding re-regulation of the labour market and a renewal of the welfare state. Thus, the SPD's 'Agenda wing' simply did not exist in union circles.

From the unions' perspective, the German employment system suffers from deregulation, permanent austerity in the public sector and creeping privatisation. In this context, the decline of traditional employment sectors is pointed to by longterm reductions in the coverage rate of collective wage agreements between unions and employers. Only around half of all employees are still covered by collective agreements, and union membership has fallen below the 20 per cent mark. There has also been a large degree of privatisation in the communication, transport and health sectors which usually brings with it a significant deterioration in the terms and conditions of employees in the affected sectors.

On the other hand, some public services have also been expanded, especially with regard to childcare and health services for senior citizens. Most employees in these sectors are female, and their work is often treated as 'unqualified' and is poorly paid. The service workers' union, Verdi (now the second largest German union by membership), has supported strike action by nursery teachers to improve their pay and conditions. However, municipal employers in the public sector are consistently unwilling to increase wages. The municipalities argue that they are under pressure to balance their budgets. Budget balance has in some cases been written into regional constitutions (for example in the state of Hesse). Such developments point to increasing divisions in the socio-economic positions of employees in different sectors, such as between those in booming export industries and those employed in public services suffering from state-imposed austerity.

\section{Electoral strategy: three choices for the SPD}

No matter how one interprets the structural changes in the labour market, it is not convincing to claim that such changes 'overdetermine' the electoral strategy of the SPD. Rather, the party continues to have different options and can exercise choices-consciously or unconsciously. The traditional strategy used to be to bring the interests of different sectors of employees and of 'winners' and 'losers' into some sort of equilibrium in order to maximise electoral appeal. This 'coalition of employees' approach used 
to be the SPD's line, before the Schröder years.

A second strategy is to appeal primarily to the winners of structural change in the labour market, repositioning the SPD as the representative of middle-class employees with high aspirations. In this case, the party must compete with the centre-right to strike a new balance focusing on cuts in welfare state provisions and support for 'self-responsibility' and 'entrepreneurship'. This approach was certainly favoured by the 'Agenda wing', which targeted all electoral efforts at what SPD leaders back then referred to as the 'new centre of employees'. However, this second strategy, at play during the 2005 and 2009 SPD federal election campaigns, suffered from two significant disadvantages, namely that the SPD voluntarily vacated its earlier claim to represent solidarity and social justice and, by trying to copy a competing party - namely the CDU/CSU-focused all efforts on centrist voters that were already targeted by a credible competitor.

Finally, a potential third strategy could be to appeal mostly to the 'losers' of structural change, to strengthen the focus on solidarity and egalitarianism and to renew the SPD's earlier alliance with the trade unions. However, this third strategy has never been seriously contemplated due to party leaders' conviction that the victims of structural economic change are those least likely to vote in elections, and therefore least promising in terms of an electoral strategy.

What makes the choice of electoral strategy more complicated for the SPD is that the different socio-economic target groups are also internally divided in terms of their normative orientation. While some favour solidaristic and egalitarian policies, others might demand authoritarian and/or paternalistic ones. To be sure, this conflict is too often presented as a simple dichotomy between libertarian and authoritarian values. The new middle classes are claimed to be close to the former pole, while the economically disadvantaged are held to be open to rightwing populist demands. However, one should appreciate that the voters of the SPD might hold different values and attitudes in different contexts. Crucially, authoritarian values and the exclusionary logic of 'competition'—which suggests punishment of 'losers'-have been part and parcel of the 'new' SPD, and emerged first and foremost in the context of neoliberal 'modernisation'.

Thus, abandoning the 'losers' of socioeconomic change, as was the case during the Schröder years, is a form of authoritarianism, and the removal of social protection does not just impose electoral costs. This kind of SPD authoritarianism-a feature of Schröder's arriviste style and that of his successor Müntefering, who preached labour discipline and frugality during his time as SPD Vice Chancellor to Angela Merkel and as labour minister between 2005 and 2009had an element of farce: it refused to make explicit that the SPD had shifted its ideological investment towards 'competitiveness' at the level of society and the individual. In short, by 'announcing to the social staterooted milieus that the process of modernization was not expected to be backed up by the welfare state or the protection of achieved social status, neither regarding working life nor with concern to old age and pensions', the SPD leadership voluntarily cut its links with disadvantaged groups. ${ }^{12}$

Such a strategic shift meant that the idea of oppression, a structural polarity between rulers and ruled, disappeared from the discourse of the official left' and was 'replaced by the neutralizing notion of the "social contract".'13 Moreover, to invoke the 'autonomous subject' meant 'in the name of an apparently necessary "individualization" ... legitimizing the retrenchment of labour laws, of social security systems and generally of the mechanisms of societal solidarity and redistribution' ${ }^{14}$

If one considers the three scenarios outlined above, the SPD's electoral approach in the twenty-first century has been to follow the second strategy (i.e. to appeal to the winners of modernisation). In short, the SPD 'does no longer aspire to be a left people's party (Volkspartei) of the middle and lower social layers' but intends to be a 'party of the new centre focusing its concern on resourcestrong employees with educational aspirations'. This implies that the party 'is no longer able to integrate the lower fifth of society'. ${ }^{15}$

The problem with this strategy, of course, is that it has never worked. The leadership's turn away from the party's core electorate did not produce any sizable gains elsewhere. 
The exclusive focus on the centre ground, already subject to the offerings of all electoral competitors with the exception of the Left Party, helped to reinforce neoliberal values. Those failing to adapt to new times and a lean welfare state were considered to be social failures in need of sanctions and punishment. In addition, they could safely be ignored when fighting elections.

Thus, the SPD's shift to the centre ground appeared as a surrender of earlier solidaristic values and prepared the ground for some of the party's electorate to consider turning even further to the right. After all, if the SPD accepted ideas that had in the past been antagonistic to its core values, namely 'discourses of just inequality [i.e. those based on meritocracy], a lean state, focus on selfresponsibility, or the apparent contradiction between old and modern social democracy', their relative difference to the political offerings of the right wing appeared to become less significant. ${ }^{16}$ The ideology of everyday life pushed for by the SPD during the welfare retrenchment years stressed that 'there is not enough for everyone', which prepared the ground for the demoralisation of the SPD's traditional core supporters. The latent fear of downward social mobility in Germany is widespread and was reawakened and radicalised by the external challenge of the 2015 refugee crisis, pointing to the fact that the country is, after more than a decade of austerity and retrenchment, poorly prepared to integrate newcomers.

\section{Conclusion: what new role for the SPD in a transformed party system?}

Three points require further clarification. First, how does the changed role of the SPD relate to the broader transformation of the German party system? Second, how does the SPD relate to projects offering a left-of-centre alternative to Merkel's centre-right CDU/ CSU? Finally, is there any conceivable strategy to recover electoral support for the SPD and to produce a renaissance of social democracy in Germany?

First, the SPD's decline from a large to a mid-sized party is part of the broader transformation of the German party system, which started out in the late 1950s as a twoparty system in which a third, small party (the liberal FDP) often held the balance of power between the centre-left SPD and the centre-right CDU/CSU. In the 1980s, the Greens emerged, initially as a leftist alternative to the SPD, while the FDP turned to the right. This produced the two-camp and fourparty political system of red-green (SPD and Greens) versus the bourgeois centre-right (CDU/CSU and FDP). The 1990s added the post-communist East German PDS, as the furthest left party, to what then became a five-party system. Since 2013, the AfD has emerged as a strong sixth party located to the right of the CDU/CSU, and has mobilised against Angela Merkel's decision, in the second half of 2015, to open Germany's borders to refugees and migrants.

Summing up the transformation of the German party system, it has turned from a two-party system to a fluid four-, five- or six-party system (the liberal FDP and the Left Party have sometimes failed to gain parliamentary representation in certain regions). Moreover, the decline of the SPD produced for some years, until 2015, a 'multiparty system with a predominant party' (namely the $\mathrm{CDU} / \mathrm{CSU}$ ), while the recent major electoral losses of Merkel's Christian Democrats to the AfD in 2016 now potentially point to a 'multiparty system without a predominant party'. ${ }^{17}$ Nevertheless, for many years the decline of the two former people's parties, the CDU/CSU and SPD, proceeded in an asymmetric manner: the SPD suffered a much greater decline than the CDU/CSU and is now a party with little more than 20 per cent of electoral support, while even after its recent losses the CDU/CSU can still command more than 30 per cent support.

Overall, the rise of the AfD indicates a significant shift to the right in Germany's political balance of forces. This is all the more significant due to the AfD's ability to gather electoral support from all sides of the party spectrum, including blue-collar workers, the unemployed and former non-voters (many of them in turn former SPD voters). In this context, it is often claimed that former supporters of the left now drifting to the AfD are voting 'against their own interests'. While this is to some extent true, given that the AfD has a strong market-radical wing 
demanding cuts in social spending and deregulation, one must also acknowledge that the SPD has deeply alienated voters from disadvantaged milieus by completely disregarding their socio-economic interests and blaming them for their failure to successfully adapt to market-driven modernisation. Thus, many former SPD voters might believe that voting for the AfD is the best way to, in turn, show their own disregard for the 'new' SPD.

This raises the second issue of how the SPD, Left Party and Greens might successfully form a centre-left alliance, and perhaps even a future government, in the context of a transformed German party system that now also includes the rightist AfD. Here it has frequently been argued that the SPD's turn to embrace many features of neoliberalism is simply too far advanced to be reversed. In the same context, observers have suggested that the Left Party might now qualify as a kind of ersatz SPD, representing blue-collar workers and the disadvantaged milieus that have been lost by the SPD, while the Greens might appeal to a centrist faction of the middle class. Overall, it is argued that the future of the centre-left might be a division of labour: the SPD marches in the middle while the Left and the Greens form wing parties.

This 'convoy strategy' suffers from serious shortcomings, however. The Left Party has in practice failed to gain stable access to blue-collar voters and disadvantaged groups. Most of the voters who moved in 2009 from the SPD to the Left Party have drifted away again, either to non-voting or, more recently, to the AfD. Furthermore, the Left Party has been unable to improve the social positions of its core constituency: past coalition governments of the SPD and Left Party in Germany's eastern regions did not resist the structural pressures of neoliberal capitalism.

In the case of the SPD and Left Party government in Berlin between 2001 and 2011, for example, the Left Party was involved in the privatisation of around 200,000 housing units and agreed to deregulate employment contracts in the public sector. The Left Party then lost around half of its vote share in 2011-a striking parallel with the earlier experiences of the SPD. ${ }^{18}$ Thus, the Left Party shares the SPD's difficulty in mobilising potentially progressive voters from disadvantaged groups. The ersatz SPD is always in danger of being too close to the original and must make efforts to retain its independent profile in order to be able to engage in social mobilisation.

By contrast, the Greens are today a party of the bourgeois centre rather than a stable component of the left political camp. In principle, the Greens can form coalition governments with both the centre-left and the centre-right. It is therefore not possible for the SPD or Left Party to rely on the Greens to engage in a division of labour. Overall, the prospects for a 'convoy strategy' of the left thus look rather bleak. In fact, the share of Germany's left vote has fallen in the early twenty-first century, and there currently exists little societal inclination to turn to a red-red-green 'convoy' for an alternative political course.

Last, one must not overlook what is patiently obvious: the centre-left SPD will not be able to recover politically without credible offers to socially disadvantaged groups. The SPD's turn, since 2003, to the centre and neoliberalism has backfired in the German context, in which the proportional electoral system allows voters more choice than is the case under the Westminster model. Neither disadvantaged groups nor blue-collar voters will vote for the SPD, or even the Left Party, if these parties fail to accommodate their social interests, especially meaningful social protection and redistributive policies. Such a turn back to one's own former voters is of course not going to make social democracy recover overnight. Yet without such turn, the crisis of the SPD will only deepen further, and the idea of a renaissance of social democracy will remain utopian.

\section{Notes}

1 W. Streeck, 'Nach dem Korporatismus: Neue Eliten, neue Konflikte', in H. Münkler, G. Straßenberger and M. Bohlender, eds, Deutschlands Eliten im Wandel, Frankfurt/M., Campus, 2005, pp. 149-75.

2 C. Butterwegge, Hartz IV und die Folgen. Auf dem Weg in eine andere Republik?, Weinheim, Beltz Juventa, 2015, pp. 58-68.

3 J. M. Dostal, 'Die Bundestagswahl 2013: Demokratische Beteiligungslücke und Dauer- 
krise der SPD', Zeitschrift der KoreanischDeutschen Gesellschaft für Sozialwissenschaften, vol. 23, no. 4, 2013, pp. 75-122.

4 C. Trampusch, 'From interest groups to parties: the change in the career patterns of the legislative elite in German social policy', German Politics, vol. 14, no. 1, 2005, pp. 14-32.

5 S. Nawrat, Agenda 2010 - ein Überraschungscoup? Kontinuität und Wandel in den wirtschafts- und sozialpolitischen Programmdebatten der SPD seit 1982, Bonn, J. H. W. Dietz, 2012.

6 No stated author, 'Sigmar Gabriel: SPD will säumigen Unterhaltszahlern Führerschein abnehmen', Zeit online, 9 August 2016. Opinion polls suggested shortly afterwards that two thirds of the German public reject the idea of withdrawing driving licences as a punishment in contexts other than traffic violations.

7 No stated author, "'Soziale Stabilität nicht aufs Spiel setzten", Sigmar Gabriel fordert Solidarpakt zugunsten der Einheimischen', Hessische/Niedersächsische Allgemeine, 8 August 2016.

$8 \mathrm{H}$. Kahrs, 'Jenseits der Statistiken sozialer Ungleichheit - Facetten modernisierter Beziehungen zwischen Arbeitswelt, Lebenswelt und Politik', Sozialismus, vol. 43, no. 7/8, 2016, pp. 6-10.

9 lbid., 6.

10 O. Nachtwey, 'Soziale Ungleichheit in der Abstiegsgesellschaft', Frankfurter Allgemeine Zeitung, 15 June 2016.
11 The decision to bring in private pension insurance (the 'Riester-Rente') suffered from its beginnings from a lack of credibility. In the meantime, the European Central Bank's low interest rate policy places a question mark behind any longterm protection of such savings.

12 Kahrs, 'Jenseits der Statistiken sozialer Ungleichheit', p. 7.

13 D. Eribon, 'Wie aus Linken Rechte werden. Der vermeidbare Aufstieg des Front National', Blätter für deutsche und internationale Politik, vol. 61, no. 8, 2016, pp. 55-63.

14 Ibid.

15 F. Walter, Vorwärts oder abwärts? Zur Transformation der Sozialdemokratie, Frankfurt/M., Suhrkamp, 2012, pp. 111, 114.

16 M. Reinhardt, S. Stache and K. Burmeister, 'Zurückgefallen hinter eine erstarkte neue Rechte: Die SPD in der doppelten Krise der Repräsentation', Sozialismus, vol. 43, no. 6, 2016, pp. 27-32.

17 J. Blondel, quoted in S. B. Wolinetz, 'Party systems and party system types', in R. S. Katz and W. Crotty, eds, Handbook of Party Politics, Los Angeles, Sage, 2006, pp. 51-62.

18 L. Redler, "NNormale kapitalistische Entwicklung". 10 Jahre Rot-Rot in Berlin', in T. Gleiss, I. Höger, L. Redler and S. Stanicic, eds, Nach Goldschätzen graben, Regenwürmer finden. Die Linke und das Regieren, Köln, PapyRossa, 2016, pp. 139-49. 